\title{
Transformation of Virus- Resistant Genotype of Gossypium hirsutum L. with Pesticidal Gene
}

\author{
Asifa MAJEED, Tayyab HUSNAIN* and S. RIAZUDDIN \\ National Centre of Excellence in Molecular Biology, \\ 87-Canal Bank Road, Thoker Niaz Baig, Lahore-53700, Pakistan \\ *Corresponding author E-mail address:
}

Received 20 October 1999; accepted 25 January 2000

\begin{abstract}
Genetically transformed plants of virus- resistant genotype of Gossypium hirsutum L. CIM- 443 were generated by using Agrobacterium and particle bombardment method. An insecticidal cry $1 A b$ gene derived from Bacillus thuringiensis was introduced in the plants. Inoculated tissues were selected on MS medium containing kanamycin. The resultant plants showed protection against Lepidopteran insect Helicoverpa armigera. Molecular analysis showed the presence of crylAb gene in the genome of transformed plant. Immunological analysis of the transgenic plants indicated expression of Cry $1 \mathrm{Ab}$ protein upto $100-120 \mathrm{ng}$ per $\mathrm{mg}$ of fresh leaf weight.
\end{abstract}

\section{Introduction}

Cotton is a perennial woody shrub cultivated in more than 90 countries. It provides food, fiber, and fuel. It is grown primarily for fiber but seeds are an important source of food both for human and livestock. Unfortunately cotton is susceptible to attack by more than 15 insects including Lepidopteran as a major pest. According to recent reports, $37 \%$ of crop production is lost to pest and diseases while 20 $-40 \%$ is directly destroyed by different pests of cotton (Ahmad, 1999). Major cotton pests has developed resistant to pesticides due to its excessive use. Moreover cotton leaf curl virus (Whiteflytransmitted Gemini virus) resulted in a significant loss of cotton production in addition to insect attack. The cotton leaf curl virus is a disease caused by Gemini virus and has been a serious problem in Indo-Pak Sub-Continent and Sudan. Whitefly transmitted Gemini virus cause serious losses to many other crops like beans, tomato (Rojas et al., 1993) and cotton (Mansoor et al., 1995) in tropical and sub-tropical regions. This disease was first time reported in Nigeria in 1912 and recorded in Sudan in 1924 (Mahboob et al., 1995). In Pakistan, the disease has resulted in a loss of 4.98 million bales of cotton with an estimated value of US $\$ 7.4$ billion (Mansoor et al., 1995).

Control of these losses is a major problem of breeders and farmers. Modern development in the field of genetic engineering has enabled the intro- duction of genetic material from any source into major crops. Genes encoding pesticidal protein have been introduced in major crops to breed the valuable trait of insect resistance. Bacillus thuringiensis, a soil bacterium, encodes for crystal proteins. These crystal proteins are the principle source of toxicity against many insect pests. These toxins are effective against many insect pests but are safe to human beings, birds and non-target insects (Soares, 1995). Agrobacterium-mediated transformation is most commonly used method for cotton transformation. But difficulties exist due to low efficiency of regeneration of cotton plants and low efficiency of transformation (Firoozabady et al., 1987; Grierson and Covey, 1988). To overcome this barrier of regeneration, particle bombardment method has been used to transform recalcitrant crops (Christou, 1992; John and Keller, 1996; McCabe et al., 1988; McCabe and Martinell, 1993). Recently it has been shown that particle bombardment of plant tissues enhances the transformation efficiency through Agrobacterium (Bidney et al., 1992; Finer and McMullen, 1990).

In the present study, a virus-tolerant genotype of cotton was used to develop insect resistant cotton plants. Plants were developed containing insect resistant gene cry1Ab. This is the first report of introduction of an agronomically important gene in a virus-resistant genotype. It also represents the first report of transformation of a virus resistant genotype of cotton with Bt gene by a combination of particle bombardment and Agrobacterium 
mediated methods. Gossypium hirsutm variety CIM -443 was selected the as a target material. This variety has been bred for resistance against cotton curl virus disease (Mehmood, 1999). Transformation of virus-resistant genotype with insecticidal Bt gene could prove a novel addition in cotton germplasm having pest and disease resistance.

\section{Materials and Methods}

\subsection{Transformation of CIM-443}

Seeds of Gossypium hirsutum L. CIM-443 obtained from Central Cotton Research Institution Multan, surface sterilized with a solution of $0.1 \%$ $\mathrm{HgCl}_{2}$ and $0.1 \%$ SDS. Mature embryos were isolated from germinating seeds and bombarded with tungsten particles. Tungsten particles were suspended in water at concentration of $60 \mathrm{gl}^{-1}$. A home made particle gun (Husnain et al., 1994) was used to bombard tungsten particles. All the conditions were strictly followed except the distance. The distance was set at $22 \mathrm{~cm}$ between filter assembly and target tissue. Agrobacterium strain C58 used in this work was harboring $\mathrm{Bt}$ insecticidal $c r y 1 A b$ gene \& NPT II marker gene (Aarssen et al., 1995). This vector (p2845) is containing the Bt gene driven by CaMV 35S promoter (Fig. 1). A loopful of bacterial cells from agar surface was inoculated in $20 \mathrm{~m} l$ YEP broth supplemented with $50 \mathrm{mg} l^{-1}$ kanamycin (Sigma), $320 \mathrm{~g}^{-1}$ spectinomycin, $1 \mathrm{mg} / \mathrm{ml}$ streptomycin, $20 \% \mathrm{MgSO}_{4}, 20 \%$ sucrose, $10 \mathrm{mg} / \mathrm{ml}$ Thiamine. $\mathrm{HCl}$ contained in $100 \mathrm{ml}$ conical flask for $24-48 \mathrm{~h}$ at $26^{\circ} \mathrm{C}$ on a rotatory shaker $(150-190$ $\mathrm{rpm})$. The bacterial cells from the flask were harvested by centrifugation at $3000 \mathrm{rpm}$ for $10 \mathrm{~min}$. and the pellet was suspended in $10 \mathrm{ml}$ MS broth (MS medium without solidifying agent) and transferred to sterilized petriplates (Murashige and Skoog, 1962). After bombardment with tungsten particles (without DNA) the mature embryos were co-cultivated with Agrobacterium for $30 \mathrm{~min}$. and cultured on MS medium for three days at $28^{\circ} \mathrm{C}$, and were transferred to selective medium containing $100 \mathrm{mg}^{-1}$ kanamycin (Sigma) and $250 \mathrm{mg} l^{-1}$ cefotaxime. After two months selection, green and growing plants were shifted to MS medium without kanamycin.

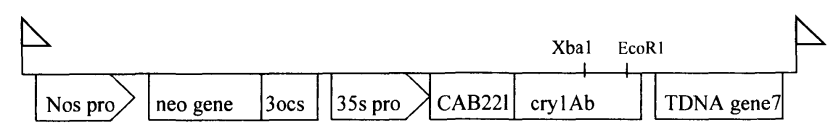

Fig. 1 Partial map of the vector used for transformation of Gossypium hirsutum CIM-443.

\subsection{Immunological Analysis}

Western and ELISA were performed for the detection of expression of Bt Cry1 Ab protein in the plant tissue. Plant extract was prepared by grinding leaves in liquid nitrogen (Draper et al., 1988). Extract was centrifuged at $14000 \mathrm{rpm}$ for $20 \mathrm{~min}$. Supernatant was taken and protein was quantified spectrophotometrically by dye binding assay (Bradford, 1976). Protein samples were electrophoresed on 12\% SDS-PAGE (Laemmli, 1977) and blotted to nitrocellulose membrane for $1 \mathrm{~h}$. The blot was processed in rabbit anti-crylAc primary antibody solution and alkaline phosphatase conjugate goat anti-rabbit IgG secondary antibody.

\subsection{Insect bioassay}

Entomocidal activity of transgenic plants of CIM443 expressing Cry1 Ab insecticidal protein was evaluated. The insect bioassay was performed on detached leaves. From each plant, three leaves were used in three replicates. The second instar larvae of Helicoverpa armigera were starved for $2 \mathrm{~h}$ before bioassay. These plants were screened for Bt protein expression against Helicoverpa armigera.

\subsection{Dot blot analysis}

The presence and expression of cry $1 A b$ gene in plant genome was detected by dot blot analysis. Ten $\mu \mathrm{g}$ DNA was spotted by pipetman on nitrocellulose membrane with positive control of cry $1 A b$ gene (Sardana et al., 1996) and negative control of nontransformed plant protein. DIG DNA labeling and detection kit Cat No. 1093-657. (Boehringer Mannheim) was used for this purpose. The probe was prepared from plasmid and rest of the process performed as described by the manufacturer.

\section{Results}

\subsection{Transformation of CIM-443}

The mature embryos co-cultivated with Agrobacterium tumefaciens produced plants on MS medium containing $100 \mathrm{mg} \mathrm{l}^{-1}$ kanamycin. Kanamycin was added to act as selective agent. The nontransformed plants became bleached or brown on medium containing kanamycin (Fig. 2). The percentage of plant growing on selection medium was determined and found to be $9.6 \%$ (Table 1). Non-transformed plants also showed some growth on kanamycin but after one week became bleached and died.

\subsection{Immunological Analysis}

Western and ELISA analysis were carried out on transgenic plants. It indicated the expression of $\mathrm{Bt}$ 

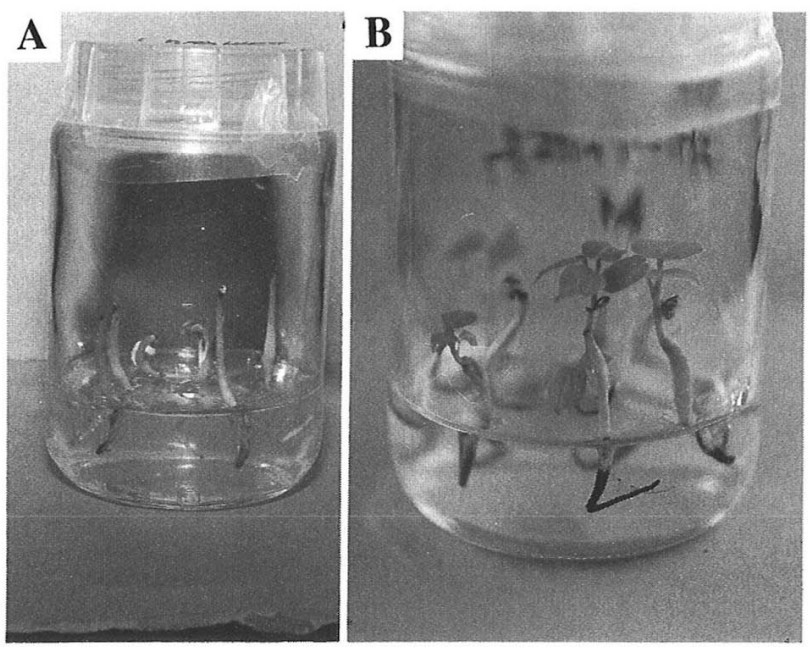

Fig. 2 Transformation of Gossypium hirsutum variety CIM-443 on selection medium.

A Control plants on selection medium.

B Transformed plants on selection medium.

insecticidal Cry1 Ab protein. Cry1 Ab protein expression in plant was $100-120 \mathrm{ng} / \mathrm{mg}$ fresh leaf weight by comparing band intensity with known amount of positive control. A predetermined amount (100 ng) of Cry1 Ab protein was used as positive control (Fig. 3). The Bt Cry1Ab protein expression was detected only in lane- 8 which corresponds to CAMB-528. In western analysis, 65 $\mathrm{KDa}$ fragment was detected. In other lanes no visible band appeared which corresponds to CAMB - 516 and CAMB-526. The Cry1 Ab protein expression in case of ELISA assay was between 50-100 $\mathrm{ng} / \mathrm{mg}$ fresh leaf weight by comparing with known amount of positive control $i-e .50 \mathrm{ng}$ and $100 \mathrm{ng}$.

\subsection{Biological activity}

Expression of the $\mathrm{Bt}$ insecticidal protein also determined by insect bioassay. American bollworm (Helicoverpa armiger) were infested on the leaves. Leaves of genetically transformed and non-transformed plants were exposed to second instar larvae of $H$. armiger and insect mortality was determined after 7-days. The insect mortality in Bt expressing plants was $44-89 \%$ (Table 2) while only $11 \%$ in case of control plant.

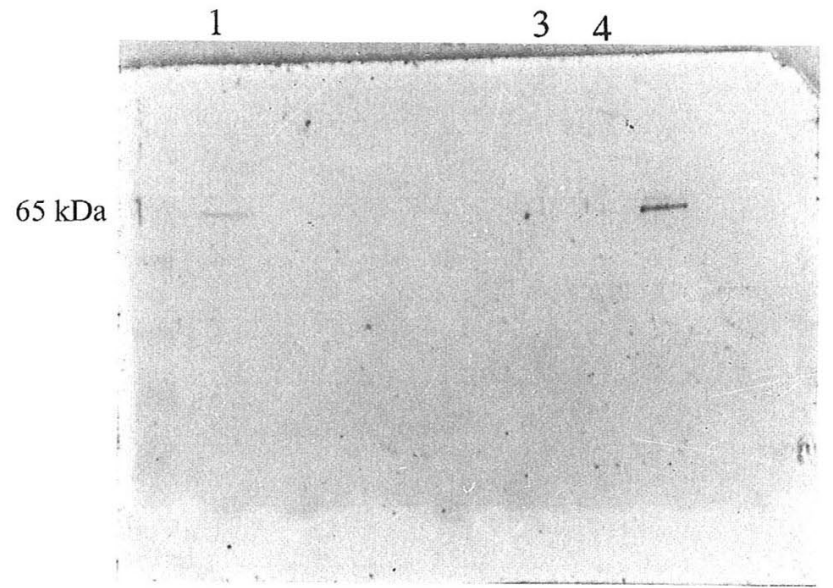

Fig. 3 Western analysis of transgenic plants.

Lane 1 Positive control.

Lane 2 Negative control.

Lane 3-5 CAMB-516, CAMB-526,

CAMB- 528 .

\subsection{Dot blot analysis}

Although detection of specific protein is an indication of the presence of foreign gene in plant. However it was further verified by dot blot analysis. The DIG DNA labeling and detection kit (Boehringer Mannheim) was used for this purpose. The results showed that the plant tested had DNA sequences that hybridized to cry $1 A b$ labeled DNA (Fig. 4). Negative control did not lit up. The positive control concentration was 5-20 ng. Therefore the band intensity indicated the presence of foreign gene in plant genome between 5-10 ng per $10 \mu \mathrm{g}$ of undigested genomic DNA.

\section{Discussion}

Cotton production and yield losses due to insect and diseases attack are the major problems in cotton growing countries. Leaf curl disease is an epidemic in Pakistan. Efforts must be made to reduce these losses and increase cotton production. In the present study, virus-resistant genotype was used to develop insect resistant cotton lines to reduce the losses caused by insects and diseases.

Key to success for transformation system is the

Table 1. Transformation of Gossypium hirsutum L. variety CIM-443 with insecticidal gene.

\begin{tabular}{cccccc}
\hline $\begin{array}{l}\text { Total No. of } \\
\text { Embryos }\end{array}$ & Control* $^{*} \begin{array}{l}\text { Plants obtained after } \\
8 \text { weeks }\end{array}$ & $\begin{array}{l}\text { Transformation } \\
\text { efficiency } 8 \text { weeks }\end{array}$ & $\begin{array}{c}\text { Plants in Soil } \\
\text { Total } \\
\text { Transformation } \\
\text { Efficiency }\end{array}$ \\
\hline \multicolumn{7}{c}{ Control } & Experimental \\
\hline 1720 & 60 & 0 & 166 & $9.65 \%$ & 89 \\
\hline
\end{tabular}

\footnotetext{
*Control plants without co-cultivation were cultured on a medium containing $100 \mathrm{mg} l^{-1}$ kanamycin.
} 
Table 2. Entomocidal performance of selected transgenic lines

\begin{tabular}{lclc}
\hline Plant No. & $\begin{array}{l}\text { Mortality } \% \\
\text { After 7-Days }\end{array}$ & Plant No. & $\begin{array}{c}\text { Mortality \% } \\
\text { After 7- Days }\end{array}$ \\
\hline CONTROL & 11 & CAMB-516 & 44 \\
\hline CAMB-502 & 67 & CAMB-527 & 78 \\
\hline CAMB-503 & 67 & CAMB-525 & 67 \\
\hline CAMB-504 & 78 & CAMB-526 & 89 \\
\hline CAMB-505 & 78 & CAMB-528 & 78 \\
\hline CAMB-507 & 83 & CAMB-529 & 44 \\
\hline CAMB-508 & 89 & CAMB-532 & 78 \\
\hline CAMB-513 & 89 & CAMB-533 & 89 \\
\hline CAMB-514 & 67 & & \\
\hline
\end{tabular}

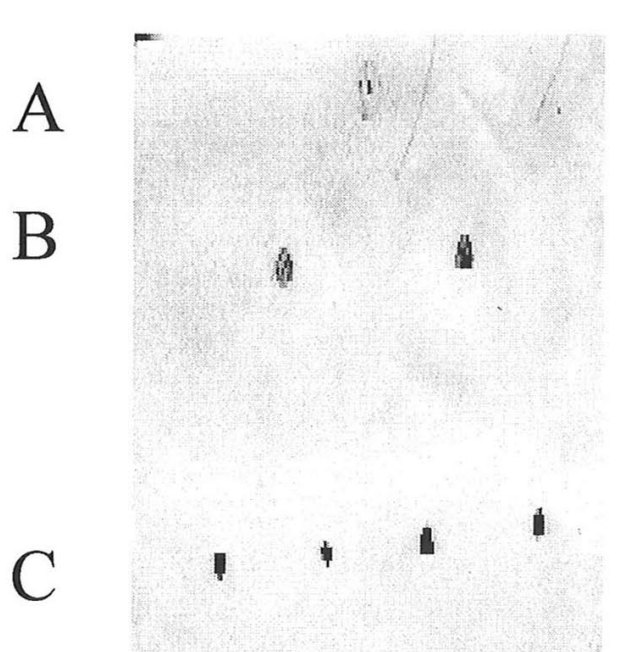

Fig. 4 Dot blot analysis of transgenic plants.

$\begin{array}{ll}\text { Lane-A } & \text { Negative control. } \\ \text { Lane-B } & \text { CAMB-528. } \\ \text { Lane-C } & \text { Positive control (5ng, 10ng, 15ng, } \\ & \text { 20ng). }\end{array}$

rapid plant development and the efficient transformation system. In present study, combination of biolistic and Agrobacterium was used for the transformation studies. The transformation system presented here differs in many ways from the work previously reported by Firoozabady et al., (1987) and Umbeck et al., (1987). In the present study, mature embryos was used as explant for the transformation of cotton. Previously callus and shoot apices were reported to be used as an explant for the transformation of cotton (Chlan et al., 1995; Firoozabady, 1987; Umbeck et al., 1987). The main advantage of mature embryo transformation is the plant development within two months in case of recalcitrant varieties.

Due to lack of an established regeneration system in virus-resistant variety, mature embryos we se- lected as explant. Consistent results have been obtained when mature embryos were used as an explant (Haris et al., 1998). Western, bioassay and ELISA results indicated the presence and expression of foreign gene in transformed plants. The transformation efficiency observed in these experiments was $9.65 \%$, better than $6.5 \%$ reported earlier in cotton by Finer et al., (1990).

The kanamycin was added to act as selective agent. It is a best way to discriminate between nontransformed and transformed plants at early stages of in vitro culture. The kanamycin level used in present study to select putative transformants was $100 \mathrm{mg} l^{-1}$. This level was higher that reported earlier by Firoozabady et al., (1987). and Umbeck et al., (1987). These authors reported that high kanamycin level $\left(50 \mathrm{mg} \mathrm{l}^{-1}-100 \mathrm{mg} \mathrm{l}^{-1}\right)$ is toxic to plant and $25-35 \mathrm{mg} \mathrm{l}^{-1}$ kanamycin level is sufficient for the selection of plants. While in case of $G$. hirsutum CIM-443 plant acquired capacity to grow on medium containing $100 \mathrm{mg} l^{-1}$ kanamycin. This difference might be due to source of explant mature embryos, callus or shoot apex. These results revealed that kanamycin level could differ from tissue to tissue and variety to variety and require optimization.

Many factors are involved in the successful integration and expression of foreign gene in plant, major being the efficient transformation method, nature of promoter and gene product. The expression of $\mathrm{Bt}$ insecticidal cry $1 \mathrm{Ab}$ gene was variable in all transgenic lines. The plants offered protection from Helicoverpa armigera showed low protein expression in immunological analysis. Some western and ELISA negative plants showed high percentage of insect mortality as compared to control plant due to presence of protein below detectable 
level. Similar results were also obtained by Perlak et al., (1990). The expression level of Bt protein in transgenic plants was $100-120 \mathrm{ng} / \mathrm{mg}$ fresh leaf weight. The reason for variable protein expression is still unclear but might be due to low copy number of gene or their insertion site in the plant genome as reported by Sachs et al., (1998).

Successful transformations of virus-resistant cotton variety with insect resistant gene, open up a way to develop insect and disease resistant plants and combing two trait could be agronomically important to increase cotton production.

\section{Acknowledgement}

The critical review of the manuscript and valuable suggestions by Dr. M. A. Qadeer and Dr. Shahid Karim are greatly acknowledged. Authors are thankful to Mohsin Ahmad Kkan, Zahoor Qadir Samra, Zakia Latif, Fareeha Zulifqar and Dr. Shahid Karim for their help to undertake these studies.

\section{References}

Aarssen, V.R., Soetaert, P., Stam, M., Dockx, J., Gossele, V., Seurinck, J., Reynaerts, A., Cornelissen, M., 1995. Cry $1 \mathrm{Ab}$ transcript formation in tobacco is inefficient. Plant Mol. Biol., 28: 513-524.

Ahmad, Z., 1999. Pest problems of cotton-regional perspective. In: Regional Consultation on Insecticide Resistance Management in Cotton June 28-July 01, 1999, p 1.Central Cotton Research Institution, Multan, Pakistan.

Bidney, D., Scelonge, C., Martich, J., Burrus, M., Sims, L., Huffman, G., 1992. Microprojectile bombardment of plant tissues increases transformation frequency by Agrobacterium tumefaciens. Plant Mol. Biol., 18: 301 313.

Bradford, M.M., 1976. A rapid and sensitive method for the quantitation of microgram quantities of protein utilizing the principle of protein dye binding. Anal. Biochem., 72: $248-254$.

Chlan, C.A., Lin, J., Cray, J.W., Cleveland, T.E., 1995. A procedure for biolistic transformation and regeneration of transformed cotton for meristematic tissues. Plant Mol. Biol. Rep., 13: 31 - 37.

Christou, P., 1992. Genetic transformation of crop using microprojectile bombardment. Plant Journal., 2: 275 281.

Draper, J., Scott, R., Armitage, P., Walden ,R., 1988. Plant genetic transformation and gene expression. A laboratory mannual, Alden Press. Oxford G.B.

Finer, J.J., McMullen, M.D., 1990. Transformation of cotton (Gossypium hirsutum L.) via particle bombardment. Plant Cell Rep., 19: 586-589.

Firoozabady, E., DeBoer, D.L., Merio, J.D., Halk, E.I., Amerson, L.N., Rashka, K.E., Murry, E., 1987. Transformation of cotton (Gossypium hirsutum L.) by Agrobacterium tumefaciens and regeneration of transgenic plants. Plant Mol. Biol., 10: 105-116.

Grierson, D., Covey, N.S., 1988. Plant Molecular Biology. 141-147 Ind edition. Blackie Chapman \& Hall. New York.

Haris, W.A.A., Husnain, T., Riazuddin, S., 1998. Transformation of cotton (Gossypium hirsutum L.) with insect resistant gene by particle bombardment and Agrobacterium. Pak. J. Biol. Sciences., 1: 170-174.

Husnain, T., Malik, T., Riazuddin, S., Gordon, M.P., 1994. Studies on the expression of marker gene in chichpea (Cicer arietinum L.). Plant Cell Tissue and Organ Culture., 44: 7-16.

John, M.E., Keller. G., 1996. Metabolic pathway engineering in cotton: Biosynthesis of polyhydroxybutyrate in fibre cells. Proc. Nalt. Acad. Sci. USA, 93: 12768-12773.

Laemmli, U.K., 1977. Cleavage of structural protein during the assembly of the bacteriophage T4. Nature., 227: 680-685.

Mahboob, A., Zahoor, A., Muhammad, T., Tariq, M., 1995. Background informaation. In: Cotton Leaf Curl Virus in the Punjab. P 4. .Central Cotton Research Institution.

Mansoor, S., Stanley, J., Malik, K.A., Markham, P.G., 1995. Molecular characterization of a geminivirus associated with cotton leaf curl virus in Pakistan. Biotechnology for Sustainable Development, (Eds Malik, Naseem and Khalid) pp: $123-128$.

McCabe, D. E., Martinell, B.J., 1993. Particle gun transformation applied to Cotton International Congress of Plant Mol. Biol. Tucson AZ.6.

McCabe, D.E., Swain, W.F., Martinell, B.J., Christou, P., 1988. Stable transformation of Soybean (Glycine max) by particle acceleration. Bio/Technology., 6: 923-926.

Mehmood, T., 1999. Cotton leaf Curl Virus disease and present Status In Pakistan In: Regional Consultation on Insecticide Resistance Management in Cotton June 28July 01, 1999. p36.Central Cotton Research Institute, Multan, Pakistan.

Murashige, T., Skoog, F., 1962. A revised medium for rapid growth and bioassays with tobacco tissue cultivars. Plant Physiol., 150: 473- 497.

Perlak, F.J., Deaton, R.W., Armstrong, T.A., Fushs, R.L., Sims, S.S., Greenplate, J.T., Fischhoff D.A., 1990. Insect resistant cotton. Bio/Technology., 8: 939-943.

Rojas, M.R., Gilbertson, R.L., Russell, D.R. and Maxwell, D.P., 1993. Use of degenerate primers in the polymerase chain reaction to detect Whitefly-transmitted Geminivirus. Plant Dis., 77: 340-347.

Sach, S.E., Benedict, H.J., Taylor, F.J., Stelly, M.D., Altman, W.D., Berberich, A.S., Davis, K.S., 1998. Expression and segregation of genes encoding Cry1A insecticidal proteins in cotton. Crop Science, 38: 1-11.

Sardana, R., Dukiandjiev,S., Giband, M., Cheng, X., Cowan, K., Sauder, C., Altosaar, I., 1996. Construction and rapid testing of synthetic and modified toxin gne sequences cry $\mathrm{A}(\mathrm{b} \& \mathrm{c})$ by expression in maize endosperm culture. Plant Cell Reports., 15: 677-681.

Soares, G.G.Jr., 1995. In Bacillus thuringiensis Biotechnology and Envirormental Benefits, (eds. By Feng, T.Y., et al.,) Vol. I, p.223-240, Hua Shiang Yuan 
Publishing Co. Taipei, Taiwan.

Umbeck, P., Jahnson, G., Barton, K. and Swain, W., 1987.
Genetically transformed cotton (Gossypium hirsutum L.). Plant Biotech., 5: 263-266. 